\title{
CONFISCATIONS DURING AND AFTER THE CIVIL WAR.*
}

Treasury Department, Office of the Secretary, Washington, February 18, 1902.

Hon. Charles C. Nott, Chief Justice of the Court of Claims, Washington, $D . C$.

Sir: I have the honor to acknowledge the receipt of your letter of the 12th inst., in which you state that a friend in England makes inquiry "whether confiscations were made after the civil war; and, if so, to what extent."

While the inquiry is limited to what was done after the close of the war, it may interest your correspondent to know what policy was pursued by the government during the war.

By the act of congress, approved March 12, 1863, the secretary of the treasury was authorized to appoint special agents to collect caputured and abandoned property in the states in insurrection. The Southern Confederacy had agents in all the cotton states, buying cotton and paying for it in Confederate bonds or currency. The cotton so purchased by the Confederate agents comprised almost the only property "captured" by the United States treasury agents during the war. If a mistake was made by these treasury agents in taking possession of property wrongfully, the secretary of the treasury, upon appeal, released the property; or, if it had been sold, the proceeds. Under the above act, the treasury agents took possession of abandoned plantations, but they were all returned to their owners, some during the war, others afterward, and no proceedings to confiscate this property were instituted. If such had been the policy and action of the government, the real estate of such a distinguished Confederate as John Șlidell, minister to France, whose property was in the possession of the treasury agents during the war, would have been among the first to be confiscated. The liberal terms granted to General Lee, when he

*This letter appeared in The London Times, April 4, 1902. 
surrendered to General Grant, are part of the history of this country, and need not be repeated here.

The rebellion had not been suppressed in all parts of the south when, on the 29 th of May, 1865, the president of the United States issued a proclamation, granting "to all persons who have, directly or indirectly, participated in the existing rebellion, except as hereinafter excepted, amnesty and pardon, with restoration of all rights of property, except to slaves." No "political conditions were laid down." There were excepted cases in the proclamation, but the parties were afterward pardoned, either by the president or by acts of congress.

It is true in some cases private property was taken and used by the Union armies, withont compensation at the time, but congress, by the act of March 3, 1871, provided a com. mission to adjudicate these claims.

You are aware that the act of March 3, 1863, which provided for the appointment of special agents to collect captured and abandoned property, provided also that "any person claiming to have been the owner of any such abandoned or captured property may, at any time within two years after the suppression of the rebellion, prefer his claim to the proceeds thereof in the court of claims."

Thus, during the war and until August 20, 1868, (the rebellion was officially declared suppressed August 20, 1866), your honorable court had jurisdiction of all claims for captured and abandoned property. The records of your court will show that judgments were entered for large sums in favor of persons who had been active and prominent in the rebellion.

A large amount of cotton was seized by the treasury agents after the rebellion had collapsed but had not been entirely suppressed.

The right to file claims in the court of claims having ceased August 20,1868, congress provided another remedy for those who claimed that cotton had been wrongfally seized, 
and passed the act of May 18, 1872, which provided that the secretary of the treasury should return the proceeds derived from the sale of cotton illegally seized after June 30, 1865. A large number of claims were filed under this act, but in nearly all cases it was found that the claimants had sold the cotton to the Confederacy, and it was, therefore, Confederate cotton when it was seized.

In reply to the specific inquiry of your correspondent I will state that contiscation through the courts, as nearly as can be ascertained, amounted to less than $\$ 200,000$.

You state that my reply will not be made public without my consent. As the facts above stated are public bistory you are at liberty to use this reply as you may deem proper. Respectfully,

I. M. Shaw, Secretary.

Davenport - We had the pleasure, two weeks ago; of visiting this, one of the most flourishing towns in Iowa. No one, we will venture to say, has visited it without being highly pleased with the beauty of location, its cleanliness, its evident prosperity, and the energy and enterprise of its inhabitants. Indeed, the beauty of its location can hardly be surpassed on the river. The town, built on a natural levee, running from the water's edge to the bluffs, presents an unequalled landing the whole length. The bluffs rising. behind the town, crowned by the fine building of the Iowa college, and some beautiful residences, Rock Island a little above on which is Fort Armstrong, Stephenson, or Rock Island City, opposite in Illinois, the islands below, with the majestic Mississippi to fill up the picture, present a view unequalled. Davenport has a large number of fine buildings, among which are the court house, college, and several: churches. She also has considerable machinery in operation.-Western Democrat, Andrew, Iowa, June 21, 1850.

VoL. VI-i. 
Copyright of Annals of Iowa is the property of State of Iowa, by \& through the State Historical Society of Iowa and its content may not be copied or emailed to multiple sites or posted to a listserv without the copyright holder's express written permission. However, users may print, download, or email articles for individual use. 